\title{
ANALIZA DOSTĘPU DO LINIOWEJ INFRASTRUKTURY OCHRONY ŚRODOWISKA W POLSCE (ZE SZCZEGÓLNYM UWZGLĘDNIENIEM WOJEWÓDZTWA WARMIŃSKO- -MAZURSKIEGO)
}

\begin{abstract}
Streszczenie
Celem badań była analiza wskaźników dotyczących dynamiki zmian dostępu do liniowej infrastruktury ochrony środowiska na obszarach wiejskich i miejskich w latach 2002-2012, w kontekście zrównoważonego rozwoju. Badaniami objęto obszary położone na terenie Polski ze szczególnym uwzględnieniem województwa warmińsko-mazurskiego. Zakres czasowy objął lata 2002-2012. Na podstawie zgromadzonych danych obliczono wskaźniki i indeksy charakteryzujące równoważenie rozwoju w aspekcie środowiskowym. Dzięki ich wynikom zauważono sukcesywny wzrost dostępności do sieci liniowej na terenach wiejskich, jednak tempo zmian w wielu przypadkach spadało w kolejnych latach. Nie stwierdzono wyraźnych odstępstw wyników dla województwa i kraju.
\end{abstract}

Słowa kluczowe: infrastruktura liniowa, ochrona środowiska, zrównoważony dostęp, tempo zmian

\section{ANALYSIS OF ACCESS TO LINEAR INFRASTRUCTURE OF ENVIRONMENTAL PROTECTION IN POLAND (WITH PARTICULAR CONSIDERATION TO WARMIŃSKO-MAZURSKIE VOIVODESHIP)}

\section{Summary}

The objective of the research was to analyse indicators concerning the changes in the access to the linear infrastructure of environmental protection in rural and urban areas from 2002 to 2012 in the context of sustainable development. The research covered Poland, with particular consideration to WarmińskoMazurskie Voivodeship. On the basis of collected data, indicators and indexes relevant for sustainable development in the environmental context were estimated. The results reveal a gradual increase in access to water mains in rural areas, however, in many cases the pace of change decreased in the following years. No distinct divergence of results was observed in the voivodeship or the country.

Key words: linear infrastructure, environmental protection, sustainable access, pace of change

\footnotetext{
${ }^{1}$ Dr inż. Mirosława Witkowska-Dąbrowska - Wydział Nauk Ekonomicznych, Uniwersytet Warmińsko-Mazurski w Olsztynie; e-mail: m.witkowska@uwm.edu.pl; dr inż. Agnieszka Napiórkowska-Baryła, Wydział Nauk Ekonomicznych, Uniwersytet Warmińsko-Mazurski w Olsztynie; e-mail: agnieszka. baryla@uwm.edu.pl; dr inż. Ilisio Manuel de Jesus - Wydział Nauk Ekonomicznych, Uniwersytet Warmińsko-Mazurski w Olsztynie, e-mail: imdj@uwm.edu.pl.
} 


\section{Wstęp}

W 2001 roku Rada Europejska przyjęła strategię zrównoważonego rozwoju Unii Europejskiej. Był to długoterminowy i kompleksowy program ukierunkowany na rozwój Europy w duchu trwałego rozwoju. W 2006 roku strategię odnowiono i rozbudowano. Stanowi ona wyzwanie dla rozwijającej się Unii Europejskiej, a zwłaszcza wstępujących sukcesywnie krajów [Kozłowski, 2007, s. 256-270]. W 2010 roku Rada Europejska przyjęła także dokument „Europa 2020 - Strategia na rzecz inteligentnego i zrównoważonego rozwoju sprzyjającego włączeniu społecznemu" jako plan na kolejne dziesięciolecie. W Polsce opracowano liczne, spójne ze sobą strategie: Strategię Rozwoju Kraju na lata 2007-2015, Strategię Rozwoju Kraju 2020 i Długookresową Strategię Trwałego i Zrównoważonego Rozwoju - Polska 2025. W tej ostatniej równoważenie jest rozumiane jako jednoczesne zapewnienie rozwoju gospodarczego i społecznego przy zmniejszeniu obciążenia środowiska na jednostkę produkcji i na jednego mieszkańca [Giordano, 2006, s. 32-34]. Od wstapienia Polski do Unii Europejskiej mija właśnie 10 lat, zatem warto pokusić się o prześledzenie zmian w dziedzinach, w których wynegocjowano okresy przejściowe. Dynamicznych zmian wymagały przede wszystkim obszary wiejskie, które zajmuja ponad 93\% terytorium Polski [Kapusta, 2007, s. 120-127]. W badaniach skupiono się na wybranych wskaźnikach zrównoważonego rozwoju w aspekcie ładu środowiskowego.

\section{Metodyka badań}

W opracowaniu przeprowadzono analizę pionową i poziomą dotyczącą wskaźników ładu środowiskowego. Analizowane wskaźniki wiązały się z wyposażeniem ludności w liniową infrastrukturę ochrony środowiska. Obszar badań objął teren Polski ze szczególnym uwzględnieniem województwa warmińsko-mazurskiego. Wyniki badań zaprezentowano odrębnie dla miast i wsi oraz ogółem dla Polski i województwa warmińsko-mazurskiego. Do badań nad zrównoważonym rozwojem liniowej infrastruktury zastosowano metodę z wykorzystaniem wskaźników i indeksów [Borys i in., 2005, s. 247-334]. Zdecydowano tak, gdyż zbiór wybranych wskaźników jest statystycznym odbiciem opisowej definicji zrównoważonego rozwoju, a indeksy pozwalają na porównanie zmian w latach, bowiem rozwój nie jest zjawiskiem stałym w czasie [Borys, 2002, s. 39-40].

Celem badań była analiza wskaźników związanych z dynamiką zmian dostępu do infrastruktury liniowej ochrony środowiska na obszarach wiejskich i miejskich w kontekście zrównoważonego rozwoju. Za obszary wiejskie uznano obszary przyjęte w polskiej klasyfikacji, a więc wszystkie poza granicami administracyjnymi miast. Umożliwiło to skorzystanie z danych statystycznych podanych przez GUS w Banku Danych Lokalnych (BDL). Badania dotyczyły lat 2002-2012. Do badań wykorzystano wybrane dane ilościowe charakteryzujące urbanizację obszarów w zakresie liniowej infrastruktury ochrony środowiska, takie jak: sieć wodociagowa i kanalizacyjna oraz gazowa (sieć infrastruktury energetycznej). Do analizy w badaniach przyjęto sieć gazowa, ponieważ 
wyposażenie w nią obszarów daje możliwości wykorzystania gazu jako źródła energii powodującego mniejszą emisję niż pozostałe kopaliny energetyczne, a jest to jeden z przyjętych wskaźników zrównoważonego rozwoju w aspekcie środowiskowym.

$\mathrm{Na}$ podstawie zgromadzonych danych obliczono wskaźniki i indeksy charakteryzujące zrównoważenie rozwoju w aspekcie środowiskowym. Przedstawiono je poniżej.

1. Udział ludności korzystającej z liniowej infrastruktury ochrony środowiska: kanalizacji, wodociagów oraz sieci gazowej (w \%). Za 100\% przyjęto ogół ludności w Polsce i w województwie warmińsko-mazurskim, rozpatrując każdy wskaźnik z uwzględnieniem liczby ludności na wsiach i w mieście [Komosa, Musiałkiewicz, 2001, s. 91-98]:

gdzie:

$$
w_{s i}=\frac{n_{i}}{N},
$$

$w_{s i}-$ udział ludności korzystającej z sieci (w \%),

$n_{i}-$ liczebność korzystających z poszczególnych sieci,

$N$ - liczba ludności ogółem.

2. Współczynnik natężenia długości sieci rozdzielczej wodociagowej przypadającej na długość sieci rozdzielczej kanalizacyjnej. Do analizy wykorzystano dane BDL dotyczące długości sieci rozdzielczej przypadającej na $1 \mathrm{~km}^{2}$ powierzchni [Komosa, Musiałkiewicz, 2001, s. 88-91]:

gdzie:

$$
w_{n}=\frac{N_{1}}{N_{2}},
$$

$W_{n}$ - współczynnik natężenia długości sieci rozdzielczej wodociagowej przypadającej na długość sieci rozdzielczej kanalizacyjnej, $N_{1}$ - długość sieci rozdzielczej wodociagowej przypadającej na $100 \mathrm{~km}^{2}$, $\mathrm{N}_{2}$ - długość sieci rozdzielczej kanalizacyjnej przypadającej na $100 \mathrm{~km}^{2}$.

3. Średnie tempo wzrostu długości sieci rozdzielczych (wodociagowej, kanalizacyjnej, gazowej) liczone według metody ř z użyciem tablic dla określonych momentów czasu [Timofiejuk, 1990, s. 8-14]. W obliczeniach zastosowano odstęp czasu $t=1$ rok. Obliczono średnie tempo wzrostu dla lat 2003-2012 w przypadku sieci kanalizacyjnej i wodociagowej oraz lat 2004-2012 w przypadku sieci gazowej. To przesunięcie o 1 rok dla sieci gazowej wynikało z tego, iż rok 2003 trzeba było przyjać za bazowy. W 2002 roku sieć gazową w danych GUS przedstawiono wraz z przesyłowa. Uwzględnienie 2002 roku prowadziłoby do zafałszowań wyników.

Podczas odczytywania średniego tempa wzrostu z tablic, w sytuacji gdy nie znaleziono dokładnie odpowiadającego sumie wyrazów faktycznego szeregu chronologicznego, przyjmowano wyniki znajdujące się pomiędzy kolejnymi liczbami $i$ wybierano tę bliższa. Taki sposób przyjmowania wyników proponuje autor metody [Timofiejuk, 1990, s. 11]: 


$$
\breve{\mathrm{r}}=\check{x}-1 \text {, }
$$

gdzie:

$\check{\mathrm{r}}$ - średnie tempo wzrostu,

$\breve{\mathrm{X}}$ - iloraz postępu geometrycznego ${ }^{2}$.

4. Dynamikę zmian w udziale korzystających $\mathrm{z}$ liniowej infrastruktury w zakresie ochrony środowiska oraz gazowej (indeks o podstawie zmiennej). Każdy rok poprzedni przyjęto za rok bazowy [Komosa, Musiałkiewicz, 2001, s. 139-150]:

gdzie:

$$
I=\frac{x_{1}}{x_{0}} \times 100 ; I=\frac{x_{2}}{x_{1}} \times 100 ; \ldots ; I=\frac{x_{5}}{x_{4}} \times 100,
$$

$I$ - indeks dynamiki o podstawie zmiennej (w \%),

$\boldsymbol{x}_{\mathbf{0}} \ldots \boldsymbol{x}_{\mathbf{4}}$ - udział ludności korzystającej z sieci w okresie podstawowym, $x_{1} \ldots x_{5}$ - udział ludności korzystającej z sieci w okresie badanym.

5. Dynamikę zmian między 2002 a 2012 rokiem w udziale korzystających z liniowej infrastruktury w zakresie ochrony środowiska oraz gazowej $(2002=100)$, $[\mathrm{Ko}-$ mosa, Musiałkiewicz, 2001, s. 139-150]:

gdzie:

$$
I=\frac{x_{1}}{x_{0}} x 100
$$

$I$ - indeks dynamiki o podstawie stałej (w \%),

$x_{0}$ - udział ludności korzystającej z sieci w okresie podstawowym,

$x_{1}$ - udział ludności korzystającej z sieci w okresie badanym.

Wyniki przedstawiono w formie omówionych rysunków i tabel.

\section{Specyfika uwarunkowań zrównoważonego rozwoju ze szczególnym uwzględnieniem obszarów wiejskich}

Duży udział obszarów wiejskich w powierzchni badanego województwa warmińsko-mazurskiego skłonił do przybliżenia specyfiki uwarunkowań zrównoważonego rozwoju na tych właśnie obszarach.

W 2012 roku obszary wiejskie w Polsce zajmowały 93,11\% powierzchni, a w województwie aż 97,53\%. Powierzchnia ocenianego województwa warmińsko-mazurskiego wynosi $24203 \mathrm{~km}^{2}$, jest to 7,7\% terytorium Polski. Ponad 54\% powierzchni stanowia użytki rolne. Warunki przyrodnicze (krótki okres wegetacji, konfiguracja terenu i zróżnicowanie gleb) stawiaja przed województwem wymóg wysokiego poziomu uzbrojenia technicznego i powoduja iż jednostkowe koszty produkcji rolniczej są wyższe, natomiast dochodowość mniejsza niż w innych regionach kraju [Strategia..., 2005, s. 19-21].

Powierzchnia użytków rolnych sukcesywnie zmniejsza się kosztem gruntów ornych oraz trwałych użytków zielonych. Zmiana przeznaczenia następuje przeważnie na cele osiedlowe i przemysłowe (prawie 60\%). Podobne tendencje można zaobserwować

\footnotetext{
2 Dokładne omówienie tej metody znajduje się w: [Timofiejuk, 1990].
} 
w całej Polsce. Od 2002 roku udział powierzchni wsi w Polsce zmniejszył się o 0,11 punktu procentowego kosztem miast, a w województwie jeszcze mniej, gdyż zaledwie o 0,01 punktu procentowego. Województwo jest jednym z mniej zanieczyszczonych w kraju. Oprócz rolnictwa, wymienia się dwa podstawowe działy produkcji związane z zasobami naturalnymi, takie jak: artykuły spożywcze i meble.

Rozwój zrównoważony ma odnosić się nie tylko do poprawy warunków ekonomicznych i społecznych, ale także do życia w czystym środowisku, z jednoczesnym wzrostem świadomości co do własnych oddziaływań na środowisko. $Z$ punktu widzenia systemów wartości uznawanych przez społeczeństwo są to pozytywne zmiany, których efektem ma być jakość życia [Kiełczewski, 2009, s. 108-119]. Sukces równoważenia rozwoju ma różne źródła. Są to uwarunkowania zewnętrzne i wewnętrzne. Do czynników wewnętrznych należy przede wszystkim wysoki potencjał społeczny i gospodarczy (zasoby wewnętrzne). Z kolei egzogenicznym źródłem sukcesu jest głównie interwencja z zewnątrz (napływ inwestycji, środki wsparcia i pomocy itp.) mająca za zadanie pobudzić obszar lub wprowadzić innowacje. Jednak dla obszarów wiejskich i miejskich te czynniki bywają różne lub występują również z różnym nasileniem. Wśród najważniejszych uwarunkowań rozwoju obszarów wiejskich należy wymienić infrastrukturalno-środowiskowe - charakteryzujące elementy infrastruktury: technicznej, społecznej, komunikacyjnej oraz jakość podstawowych elementów stanu środowiska przyrodniczego [Bański, Czapiewski, 2008, s. 3-9]. Wdrażanie zrównoważonego rozwoju odbywa się bowiem przez realizację konkretnych zadań poprzedzonych programami, które wynikają z przyjętych strategii. Kolejne zadania są realizowane w przyjętych terminach realizacji. Biorąc pod uwagę najczęściej stawiane cele zrównoważonego rozwoju, najszerzej obejmują one rozwój przestrzenny. Wymaga to wielu kosztownych inwestycji. Badania innych autorów potwierdzają działania zmierzające do poprawy infrastruktury technicznej w gminach [Adamska, 2007, s. 7-13]. Odnosząc się do infrastrukturalnych uwarunkowań rozwoju, przeanalizowano urbanizację obszarów wiejskich w zakresie inwestycji liniowych ochrony środowiska. Proces urbanizacji przebiegał przy intensywnej pomocy finansowej Unii Europejskiej.

Obszary wiejskie, według polskiej klasyfikacji, to po prostu obszary pozostające poza granicami administracyjnymi miast. Znaczne różnice pod względem rozwoju społeczno-gospodarczego na obszarach wiejskich i miejskich sa spowodowane mnogością czynników istotnie oddziałujących na tempo i kierunek zmian zachodzących na obu obszarach. Pojęcie rozwoju dotyczące miast jest dość jednoznaczne i ugruntowane, natomiast w przypadku obszarów wiejskich jest rozumiane bardzo różnorodnie [Kociszewska, 2007, s. 136-146]. Rozwój obszarów wiejskich często utożsamia się jedynie z postępującą urbanizacja, choć trudno jej nie doceniać jako jednego z grup czynników wpływających na jakość życia mieszkańców wsi [Heffner, 2009, s. 99-107]. Ważne znaczenie ma wdrażanie wielu udogodnień dla różnych grup zamieszkujących obszary wiejskie i należy je traktować nie jako cele do realizacji, a kolejne etapy służące podnoszeniu poziomu oraz jakości życia. Polityka rozwoju obszarów wiejskich przeszła szybką ewolucję po wstąpieniu Polski do Unii Europejskiej, koncertując się na zmniejszaniu dystansu polskiej wsi w stosunku do poziomu osiagniętego w krajach członkowskich. Biorąc pod uwagę rozwój liniowej infrastruktury ochrony środowiska, utrudnieniem jest to, 
że jednostki osadnicze na terenach wiejskich w Polsce na ogół charakteryzują się luźną zabudowa. Wpływa to na wydłużenie sieciowej infrastruktury. Fakt ten powoduje wysokie koszty inwestycyjne oraz wysokie koszty eksploatacji. Poszczególne gminy dokonują analizy kierunków dalszego rozwoju, zwłaszcza jeżeli chodzi o kanalizację. Istnieje bowiem alternatywne, tańsze rozwiązanie, mianowicie budowa przydomowych małych oczyszczalni ścieków [Goleń, 2011, s. 7-13]. Być może z czasem należałoby wprowadzić zmianę wskaźników zastosowanych do oceny zrównoważenia rozwoju z uwzględnieniem innych urządzeń infrastruktury ochrony środowiska. Jednak monitoring i ocena poziomu równoważenia rozwoju jest konieczna bez względu na rodzaje zastosowanych wskaźników. Natomiast problemem może być aspekt porównywalności wyników w przypadku ewentualnych zmian. Przeprowadzenie oceny wskaźników zrównoważonego rozwoju pozwala na zbadanie zmian w dostępności do liniowej infrastruktury ochrony środowiska w odstępie czasu i określenie poziomu oraz tempa zmian [Witkowska-Dąbrowska, 2010, s. 270-275]. W badaniach nad zrównoważonym rozwojem w obecnym kształcie posłużono się wskaźnikami, które proponuje Borys [Borys, 2005, s. 20-61] i Kistowski [Kistowski, 2003, s. 205-263].

Innym problemem pozostaje stwierdzenie, czy równoważenie ma polegać na zmianach ilościowych, nawiązując do problemu jakości życia obecnych i przyszłych pokoleń. Na pewno nie. Jeden z postulatów związanych z przetrwaniem ludzkości dotyczy strategii kształtowania postaw zgodnych $z$ wymogiem odpowiedzialności za właściwe człowiekowi środowisko życia. Niesie to ze soba przewartościowanie dotychczas uznawanych wartości [Łepko, 2002, s. 164]. Może to być przyczynkiem do rozważań nad ogólnym wskaźnikiem jakości życia, który być może uwzględniałby specyfikę obszarów miejskich i wiejskich.

\section{Analiza wybranych wskaźników dostępu do liniowej infrastruktury ochrony środowiska}

Z badań wynika, że dysproporcje w zakresie udziału ludności korzystającej z urządzeń sieciowych na wsi i w miastach nadal są duże, zarówno w województwie warmińsko-mazurskim, jak i w całym kraju (tabela 1.).W województwie udział ludności korzystającej z kanalizacji w badanym okresie na wsiach był znacząco niższy niż w miastach. W 2002 roku różnica ta sięgała około 70 punktów procentowych. 
TABELA 1.

Wskaźniki charakteryzujące udział ludności mającej dostęp do infrastruktury ochrony środowiska na obszarach wiejskich i miejskich, w województwie warmińsko-mazurskim i w Polsce (w \%)

\begin{tabular}{|c|c|c|c|c|c|c|}
\hline \multirow[t]{2}{*}{ Wyszczególnienie } & \multicolumn{6}{|c|}{ Lata } \\
\hline & 2002 & 2004 & 2006 & 2008 & 2010 & 2012 \\
\hline \multicolumn{7}{|c|}{ Udział ludności korzystającej z sieci kanalizacyjnej (w \%) } \\
\hline \multicolumn{7}{|c|}{ Polska } \\
\hline Miasto & 83,1 & 84,0 & 84,8 & 85,0 & 86,1 & 87,0 \\
\hline Wieś & 14,2 & 17,3 & 20,2 & 22,5 & 24,8 & 29,4 \\
\hline \multicolumn{7}{|c|}{ Województwo warmińsko-mazurskie } \\
\hline Miasto & 90,8 & 91,8 & 92,0 & 92,3 & 92,5 & 92,9 \\
\hline Wieś & 18,7 & 21,5 & 23,6 & 25,2 & 26,5 & 31,0 \\
\hline \multicolumn{7}{|c|}{ Udział ludności korzystającej z sieci wodociągowej (w \%) } \\
\hline \multicolumn{7}{|c|}{ Polska } \\
\hline Miasto & 94,2 & 94,4 & 94,9 & 95,2 & 95,3 & 95,4 \\
\hline Wieś & 69,7 & 71,3 & 72,8 & 74,2 & 75,2 & 76,2 \\
\hline \multicolumn{7}{|c|}{ Województwo warmińsko-mazurskie } \\
\hline Miasto & 96,9 & 96,9 & 97,3 & 97,4 & 97,5 & 97,5 \\
\hline Wieś & 70,6 & 72,1 & 74,1 & 75,2 & 76,3 & 77,3 \\
\hline \multicolumn{7}{|c|}{ Udział ludności korzystającej z sieci gazowej (w \%) } \\
\hline \multicolumn{7}{|c|}{ Polska } \\
\hline Miasto & 73,1 & 73,2 & 73,0 & 72,7 & 72,9 & 72,4 \\
\hline Wieś & 18,6 & 17,8 & 18,3 & 18,8 & 20,8 & 21,7 \\
\hline \multicolumn{7}{|c|}{ Województwo warmińsko-mazurskie } \\
\hline Miasto & 72,6 & 73,3 & 72,5 & 71,4 & 70,8 & 70,1 \\
\hline Wieś & 2,3 & 2,5 & 2,5 & 2,8 & 3,4 & 3,7 \\
\hline
\end{tabular}

Źródło: opracowanie własne na podstawie danych BDL.

Różnica zmniejszała się sukcesywnie, by w roku 2012 osiagnąć poziom 61,1 punktów procentowych w województwie i 57,6 w kraju. W całym badanym okresie 20022012 udział ludności w Polsce korzystającej z dostępu do sieci kanalizacyjnej wzrósł o prawie 10 punktów procentowych (rysunek 1.).

Znacznie mniejsze różnice miały miejsce w przypadku sieci wodociagowej. W 2002 roku ludność miast korzystała z niej w ponad 95\%, a wsi w ponad 70\% w województwie warmińsko-mazurskim i podobnie, choć nieznacznie mniej, w kraju. W badanych latach udział ten zwiększył się średnio dla wsi i miasta w kraju, jak i w województwie o prawie 4 punkty procentowe. W przypadku dostępu do sieci gazowej w kraju, na wsi i w miastach różnice były nieznacznie mniejsze niż w przypadku kanalizacji. W miastach z sieci korzystało ponad 70\% mieszkańców. Na wsiach udział ten nawet nie osiagnął 20\%. Ma to szczególne znaczenie dla ograniczania tzw. niskiej emisji, która występuje głównie w małych miastach i na wsiach. Zdecydowanie większe różnice w dostępie do sieci gazowej odnotowano w województwie warmińsko-mazurskim. W miastach województwa udział ludności korzystającej z sieci gazowej był podobny jak w kraju. Jednak na wsiach znacząco niższy. Zaledwie w granicach 2,3\% w 2002 roku do 3,7\% w 2012. Zarówno w kraju, jak i w województwie warmińsko-mazurskim zaobserwowano sukcesywny wzrost udziału ludności wiejskiej korzystającej z sieci gazowej. 
Jednakże w miastach stwierdzono w badanych latach niewielki spadek o około 1 punktu procentowego. Zbliżone wyniki uzyskano w badaniach przeprowadzonych w powiecie legnickim, gdzie mimo znaczącego wydłużenia sieci gazowej, gdyż aż dwukrotnie, udział korzystających z sieci wzrósł nieznacznie, zaledwie o 10\% [Szymańska, 2007, s. 338-346].

RYSUNEK 1.

Udział ludności mającej dostęp do liniowej infrastruktury ochrony środowiska w województwie warmińsko-mazurskim i w Polsce ogółem (w \%)

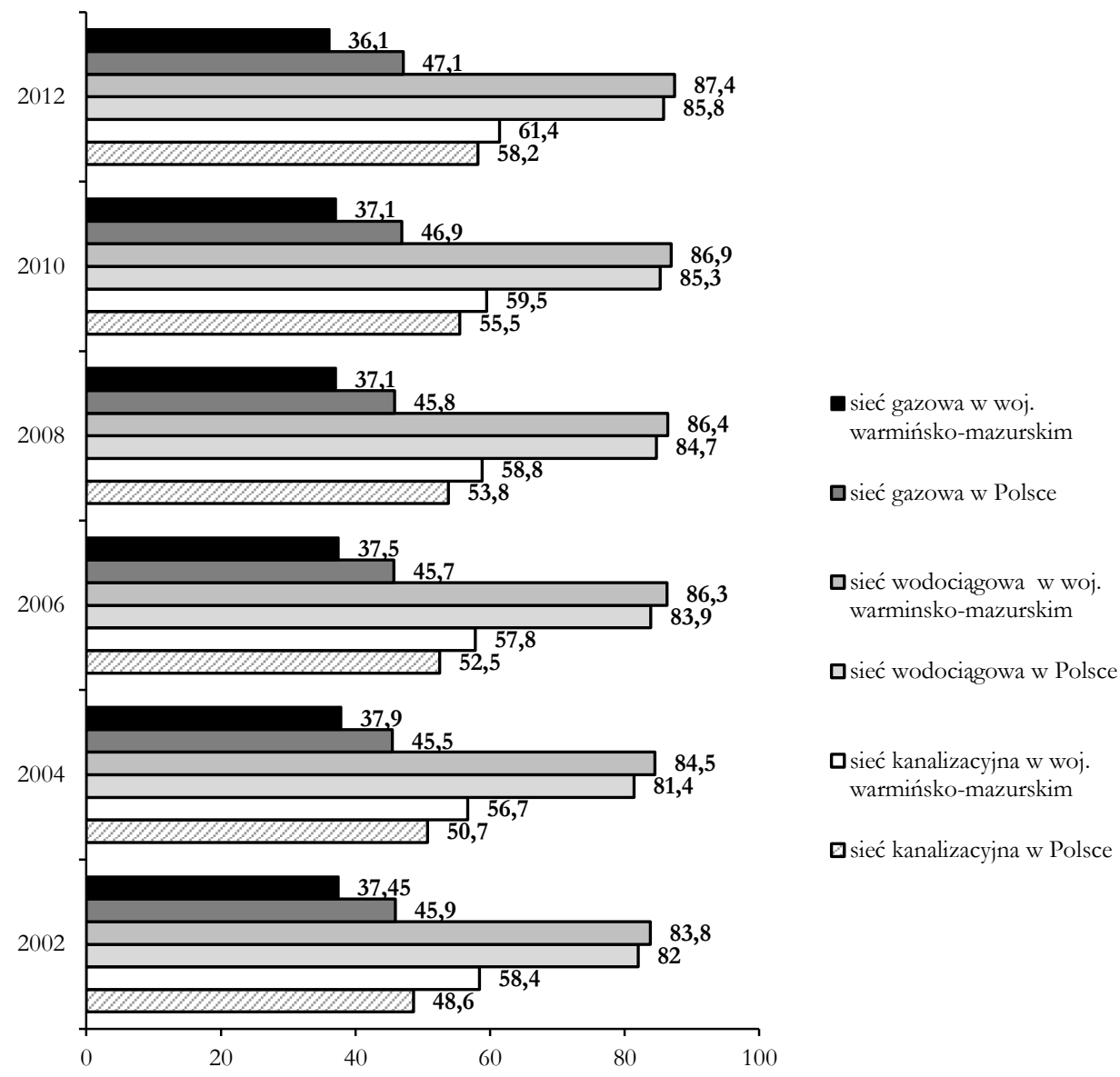

Źródło: opracowanie własne na podstawie danych BDL.

Do badań nad dynamika zmian udziału korzystających z liniowej infrastruktury wykorzystano indeksy o podstawie zmiennej. Wynika z nich, że dynamika zmian w badanych latach 2002-2012 w większości przypadków przyjmowała wartości powyżej 100\% 
(tabela 2.). Jednak nie można mówić tu o tendencji. W kolejnych, analizowanych latach były widoczne wahania w obu kierunkach z różną siłą.

TABELA 2.

Dynamika zmian w latach 2002-2012, w udziale osób korzystających z liniowej infrastruktury $\mathrm{z}$ podziałem na wieś i miasto $(\mathrm{w} \%)$

\begin{tabular}{|c|c|c|c|c|c|}
\hline \multirow{2}{*}{$\begin{array}{c}\text { Wyszczególnie- } \\
\text { nie }\end{array}$} & \multicolumn{5}{|c|}{ Lata } \\
\hline & $\begin{array}{c}2004 \\
2002=100\end{array}$ & $\begin{array}{c}2006 \\
2004=100\end{array}$ & $\begin{array}{c}2008 \\
2006=100\end{array}$ & $\begin{array}{c}2010 \\
2008=100\end{array}$ & $\begin{array}{c}2012 \\
2010=100\end{array}$ \\
\hline \multicolumn{6}{|c|}{ Sieć kanalizacyjna } \\
\hline \multicolumn{6}{|c|}{ Polska } \\
\hline Miasto & 103,3 & 101,0 & 100,2 & 101,3 & 101,1 \\
\hline Wieś & 121,8 & 116,8 & 111,4 & 110,2 & 118,5 \\
\hline Polska ogółem & 112,6 & 108,9 & 105,8 & 105,8 & 109,8 \\
\hline \multicolumn{6}{|c|}{ Województwo warmińsko-mazurskie } \\
\hline Miasto & 101,10 & 100,22 & 100,33 & 100,22 & 100,43 \\
\hline Wieś & 114,97 & 109,77 & 106,78 & 105,16 & 116,98 \\
\hline $\begin{array}{l}\text { Województwo ogó- } \\
\text { łem }\end{array}$ & 108,04 & 105,00 & 103,56 & 102,69 & 108,71 \\
\hline \multicolumn{6}{|c|}{ Sieć wodociągowa } \\
\hline \multicolumn{6}{|c|}{ Polska } \\
\hline Miasto & 100,2 & 99,7 & 100,3 & 100,1 & 100,1 \\
\hline Wieś & 102,3 & 102,1 & 101,3 & 101,3 & 101,3 \\
\hline Polska ogółem & 101,3 & 100,9 & 100,8 & 100,7 & 100,7 \\
\hline \multicolumn{6}{|c|}{ Województwo warmińsko-mazurskie } \\
\hline Miasto & 100,0 & 100,4 & 100,1 & 100,1 & 100,0 \\
\hline Wieś & 103,5 & 102,8 & 101,5 & 101,5 & 101,3 \\
\hline Województwo ogó- & & & 100,8 & & \\
\hline & 101,8 & 101,6 & & 100,8 & 100,7 \\
\hline \multicolumn{6}{|c|}{ Sieć gazowa } \\
\hline \multicolumn{6}{|c|}{ Polska } \\
\hline Miasto & 100,1 & 99,7 & 99,6 & 100,2 & 99,3 \\
\hline Wieś & 95,7 & 102,8 & 102,7 & 110,6 & 104,3 \\
\hline Polska ogółem & 97,9 & 101,3 & 101,2 & 105,4 & 101,8 \\
\hline \multicolumn{6}{|c|}{ Województwo warmińsko-mazurskie } \\
\hline Miasto & 101,0 & 98,9 & 98,5 & 99,2 & 99,0 \\
\hline Wieś & 108,7 & 100,0 & 112,0 & 121,4 & 103,2 \\
\hline Województwo ogó- & & & & 110,3 & \\
\hline łem & 104,8 & 99,5 & 105,2 & & 103,9 \\
\hline
\end{tabular}

Za podstawę przyjęto rok poprzedzający.

Źródło: opracowanie własne na podstawie danych BDL dotyczących udziału ludności korzystającej z sieci.

Dynamika poniżej 100\% dotyczyła ludności korzystającej z sieci gazowej zarówno w Polsce, jak i województwie w miastach. W miastach od 2005 roku odnotowano spadek udziału korzystających z sieci gazowej. Mogło to mieć związek ze wzrastającą ceną gazu ziemnego. Taka tendencja nie wystapiła na wsiach, lecz ogółem w Polsce zaobserwowano nieznaczny, ale sukcesywny spadek. 
Analizując zmiany w wyposażeniu w liniową infrastrukturę ogólem w Polsce i województwie warmińsko-mazurskim między rokiem 2002 a 2012, największą dynamikę zmian stwierdzono w przypadku rozbudowy sieci kanalizacyjnej w Polsce i w województwie warmińsko-mazurskim. Udział ludności korzystającej z sieci kanalizacyjnej w tym okresie wzrósł najbardziej (rysunek 2.).

RYSUNEK 2.

\section{Dynamika zmian w udziale ludności korzystającej z liniowej infrastruktury} (ogółem w Polsce i województwie warmińsko-mazurskim) w 2012 roku (w \%)

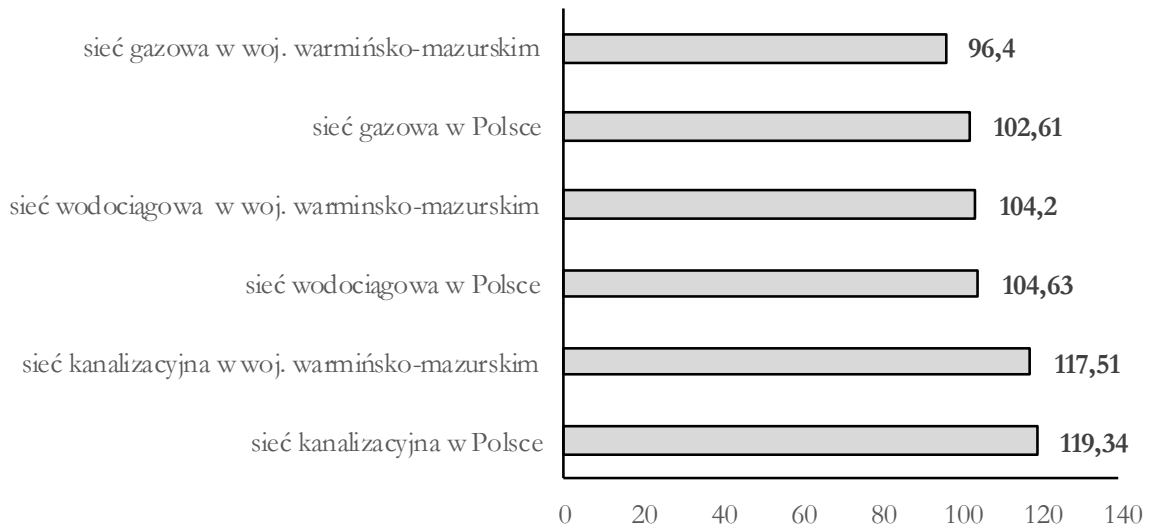

Za podstawę przyjęto rok $2002=100$.

Źródło: opracowanie własne na podstawie danych BDL dotyczących udziału ludności korzystającej z sieci.

Warto zwrócić uwagę na średnie tempo wzrostu mierzone w latach 2004-2012 i obliczone dla sieci gazowej, które przyjmowało najniższe wielkości (rysunek 3.). Najwyższe tempo w latach 2003-2112 odnotowano dla długości sieci kanalizacyjnej na wsiach zarówno w Polsce, jak i województwie warmińsko-mazurskim (ponad 12\% rocznie). W województwie średnie tempo wzrostu długości sieci wodociagowej znacząco przewyższyło ten sam wskaźnik dla Polski, zwłaszcza na wsiach, osiagając tam wielkość ponad 5\% rocznie. 
RYSUNEK 3.

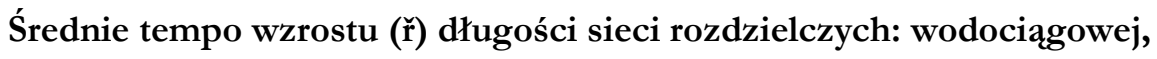
kanalizacyjnej i gazowej (w \%)

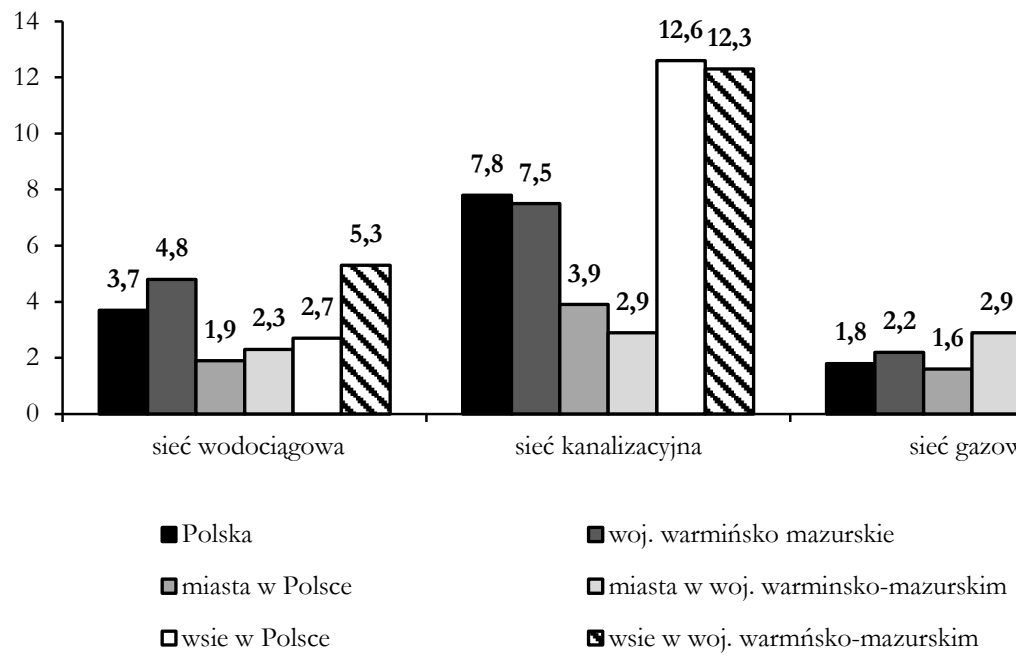

Źródło: opracowanie własne na podstawie danych BDL.

RYSUNEK 4.

Długość sieci rozdzielczej wodociagowej, przypadającej na długość sieci rozdzielczej kanalizacyjnej

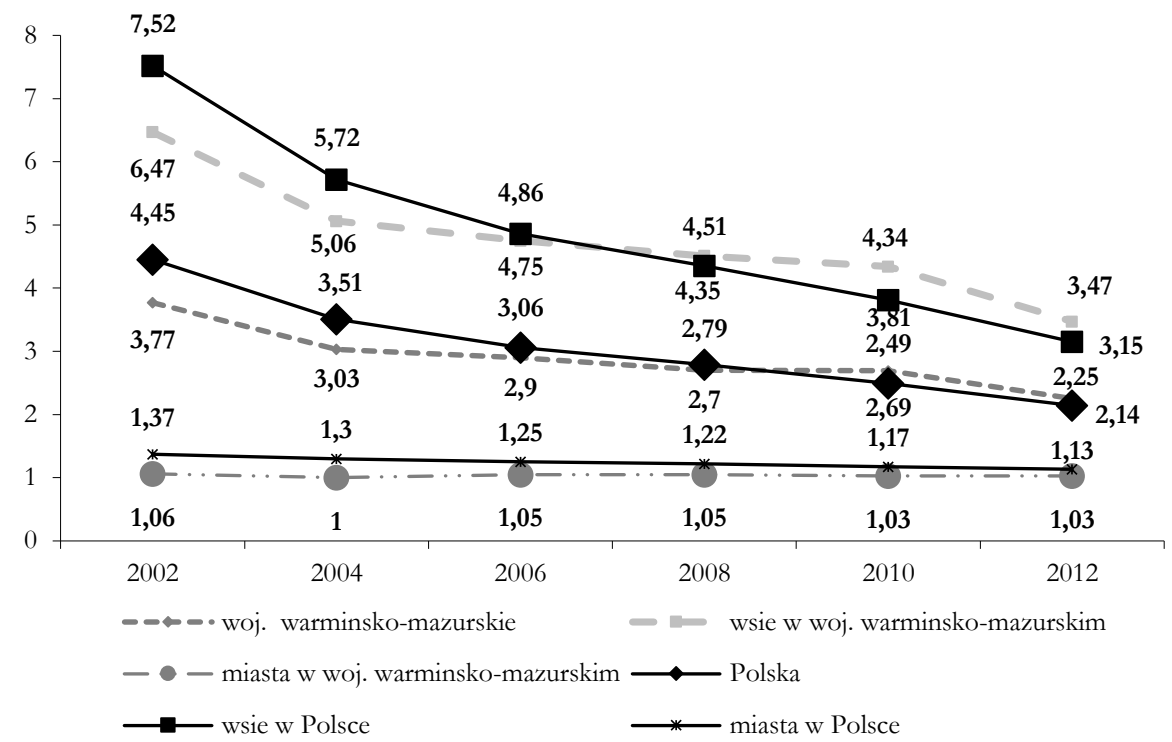

Źródło: opracowanie własne na podstawie danych BDL. 
Jednak problemem był, i nadal pozostał, stosunek obszarów objętych siecią wodociagową do obszarów objętych kanalizacją (rysunek 4.). W przypadku miast na $1 \mathrm{~km}$ rozdzielczej sieci kanalizacyjnej przypadał nieco ponad $1 \mathrm{~km}$ sieci wodociagowej. $\mathrm{Na}-$ tomiast na wsiach pięciokrotnie więcej, a to, niestety, nie sprzyjało ochronie środowiska.

Dostęp do wodociagu oznacza powstawanie większej ilości ścieków, które nie mogąc być odprowadzone bezpośrednio do oczyszczalni z braku dostępu ludności do kanalizacji. Odprowadza się je tam za pomocą wozów asenizacyjnych. Zdarza się również, że nieoczyszczone trafiaja na pola uprawne czy do kanalizacji deszczowej, a stamtąd do wód powierzchniowych.

\section{Podsumowanie}

W badaniach posłużono się wskaźnikami, które są podstawowymi miernikami stosowanymi w badaniach nad zrównoważonym rozwojem. Ich zaleta jest porównywalność oraz to że można je przekształcać w indeksy ukazujące zmienność zjawisk w czasie. Do budowy wskaźników wykorzystano dane pochodzące z ogólnodostępnej statystyki, co bardzo ułatwiło tworzenie macierzy danych. Jednak statystyka jest w pewien sposób ograniczona albo w zakresie badanych cech, albo jednostek statystycznych. W przypadku badań nad zrównoważonym rozwojem na obszarach wiejskich z wykorzystaniem danych z BDL problemem jest niewielka liczba cech statystycznych, wygenerowanych dla obszarów wiejskich, stanowiących jednostkę statystyczną. W badaniach zaprezentowano dostępność do infrastruktury sieciowej ochrony środowiska w Polsce i w województwie warmińsko-mazurskim.

Mimo intensywnego rozwoju liniowej infrastruktury, nadal istnieją wyraźne dysproporcje w zakresie udziału ludności korzystającej z urządzeń sieciowych na wsi i w miastach, zwłaszcza z sieci kanalizacyjnej i gazowej. Dostęp do liniowej infrastruktury w województwie warmińsko-mazurskim nie odbiegał od sytuacji, jaka pod tym względem występowała w kraju. Jedynie dostępność do sieci gazowej na obszarach wiejskich województwa znacząco różniła się od dostępności w kraju.

Problemem ciagle pozostaje stosunek długości sieci kanalizacyjnej do wodociagowej. Wyposażenie w sieć wodociagowa przy niedostatecznym wyposażeniu w sieć kanalizacyjną sprzyja praktykom nielegalnego pozbywania się ścieków.

Średnie tempo wzrostu i dynamika zmian wskazują na rozwój w dostępności do infrastruktury sieciowej, lecz wciąż istnieją wyraźne różnice między obszarami wiejskimi i miejskimi. Dynamiczne zmiany w stanie infrastruktury na obszarach wiejskich wynikają z większych potrzeb i zapóźnienia na obszarach wiejskich w zakresie infrastruktury ochrony środowiska, które w ramach równoważenia rozwoju należy zniwelować. Słabo rozwinięta infrastruktura na obszarach wiejskich z roku na rok ulega poprawie. Ma to istotne znaczenie w świetle zmian, które sa nieuniknione w zrównoważonym rozwoju obszarów wiejskich. Wieś powinna z każdym rokiem stawać się coraz bardziej wielofunkcyjna. Wymuszać to będzie postępująca urbanizację, ze względu na potrzebę rozwijania się na obszarach wiejskich innych działalności niż produkcja rolnicza. Dodatkowo, nieustannie przeobrażające się potrzeby społeczne skłaniają 
do zmian w dostępie do infrastruktury. Motorem napędzającym rozwój infrastruktury są środki unijne służące niwelowaniu różnic regionalnych.

\section{Literatura}

Adamska H. 2007 Wdrażanie koncepïi zrównoważonego rozwoju w gminie Kostomłoty, [w:] Teoria ipraktyka zrównoważonego rozwoju, A. Graczyk (red.), EkoPress, Białystok-Wrocław.

Bański J., Czapiewski K. 2008 Identyfikacja i ocena czynników sukcesu spoteczno-gospodarczego na obszarach wiejskich, Ministerstwo Rozwoju Regionalnego, Warszawa.

Borys T. 2002 Wskaźniki rozwoju zrównoważonego. Podstawowe kierunki badań $i$ zastosowań, Ekonomia i Środowisko, Białystok.

Borys T., Bartniczak B., Brzozowski T., Kusterka M., Ptak M., Rogala P., Sej-Kolasa M., Skowron P., Zielińska A. 2005 W skaźniki zrównoważonego rozwoju w układzie ladów, [w:] Wskaźniki zৃównoważonego rozwoju, T. Borys (red.), Wydawnictwo Ekonomia i Środowisko, Warszawa-Białystok.

Borys T. 2005 Zrównoważony rozwój jako przedmiot pomiaru wskaźnikowego, [w:] Wskaźniki zrónnoważonego rozwoju, T. Borys (red.), Wydawnictwo Ekonomia i Środowisko, Warszawa-Białystok.

Heffner K. 2009 Ewolucja zróżnicowania rozwoju spoteczno-gospodarczego obsqarów wiejskich w Polsce, [w:] Wpływ idei zrównoważonego rozwoju na polityke państwa i regionów, t. 2., B. Poskrobko (red.), Wydawnictwo Wyższej Szkoły Ekonomicznej w Białymsto$\mathrm{ku}$, Białystok.

Kistowski M. 2003 Regionalny model zrównoważonego rozwoju i ochrony środowiska Polski a strategie rozwoju wojewódz̨w, Wydawnictwo Naukowe, Uniwersytet Gdański, GdańskPoznań.

Giordano K. 2006 Planowanie zrównoważonego rozwoju w praktyce, KUL, Lublin.

Goleń M. 2011 Wprowadzenie, M. Goleń (red.), Oficyna Wydawnicza SGH, Warszawa. Inwestycje komunalne w ochronie środowiska (praygotowanie i prowadzenie inwestycii) 1997, NFOŚiGW, Warszawa.

Kapusta F. 2007 Wybrane determinanty strategii zrównoważonego rozwoju wsi i rolnictwa w Polsce, [w:] Teoria i praktyka zrównoważonego rozwoju, A. Graczyk (red.), Wydawnictwo EkoPress, Białystok-Wrocław.

Kiełczewski D. 2009 Jakość sycia $i$ dobrobyt jako kategorie zrównoważonego rozwoju, [w:] Od koncepcji ekorozwoju do ekonomii zrównoważonego rozwoju, D. Kiełczewski (red.), Wydawnictwo Wyższej Szkoły Ekonomicznej w Białymstoku, Białystok.

Kociszewska I. 2007 Niektóre społeczno-ekonomiczne uwarunkowania zrównoważonego rozwoju obszarów wiejskich, [w:] Teoria i praktyka zrównoważonego rozwoju, A. Graczyk (red.), Wydawnictwo EkoPress, Białystok-Wrocław.

Komosa A., Musiałkiewicz J. 2001 Statystyka, Ekonomik, Warszawa.

Kozłowski S. 2007 Od polityki ochrony prayrody i polityki ochrony środowiska do polityki zrównoważonego rozwoju, [w:] Obszary badań nad trwałym i zrównoważonym rozwojem, B. Poskrobko (red.), Wydawnictwo Ekonomia i Środowisko, Białystok. 
Łepko Z. 2002 Etologiczna teoria kryzysu ekologicznego, [w:] Od kosmologii do ekofilozofii, J. M. Dołęga (red.), „Episteme”, nr 22.

Strategia Rozwoju Spoleczno-Gospodarczego Województwa Warmińsko-Mazurskiego do roku 2020 2005, Zarząd Województwa Warmińsko-Mazurskiego, Olsztyn.

Szymańska J. 2007 Wyposażenie powiatu legnickiego w infrastrukture technicznnq stużqca ochronie środowiska jako praykład wdrażania koncepcji rozwoju zrównoważonego na poziomie lokalnym, [w:] Teoria i praktyka zrównoważonego rozwoju, A. Graczyk (red.), Wydawnictwo EkoPress, Białystok-Wrocław.

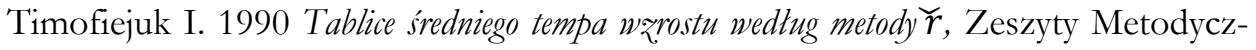
ne, nr 75, GUS, Warszawa.

Witkowska-Dąbrowska 2010 Równoważenie rozwoju na obszarach wiejskich w aspekcie tadu środowiskowego - problemy pomiaru i oceny, SERiA, t. XII, z. 1. 